\title{
Program Kemitraan Masyarakat: Pemanfaatan Pangan Lokal sebagai Sumber Asupan Gizi bagi Balita Prasejahtera Daerah Perbatasan di Kabupaten Merauke
}

\section{(Comunity Partnership Program: Utilization of Local Food as a Source of Nutrition Intake for Pre-prosperous Children of Border Areas in Merauke Regency)}

\author{
Adi Sumarsono ${ }^{*}$, Nurcholis ${ }^{2}$, Sri Winarsih ${ }^{3}$ \\ ${ }^{1}$ Jurusan Pendidikan Jasmani Kesehatan dan Rekreasi, Fakultas Keguruan dan Ilmu Pendidikan,Universitas Musamus, \\ Jl. Kamizaun Mopah Lama, Kabupaten Merauke, Papua 9961. \\ 2 Jurusan Peternakan, Fakultas Pertanian, Universitas Musamus, Jl. Kamizaun Mopah Lama, \\ Kabupaten Merauke, Papua 9961. \\ 3 Jurusan Sastra Inggris, Fakultas Keguruan dan Ilmu Pendidikan, Universitas Musamus, Jl. Kamizaun Mopah Lama, \\ Kabupaten Merauke. Papua 9961. \\ *Penulis Korespondensi: adi@unmus.ac.id \\ Diterima April 2019/Disetujui Agustus 2019
}

\begin{abstract}
ABSTRAK
Fenomena anak yang menderita gizi buruk di Kabupaten Asmat, Provinsi Papua masih menjadi bahan pemberitaan media nasional dan menjadi salah satu tolak ukur keberhasilan pemerintah dalam menerapkan program pro-rakyatnya. Kegiatan kemitraan masyarakat ini bertujuan memberikan pengetahuan, pemahaman, dan keterampilan langsung kepada warga prasejahtera khususnya di daerah perbatasan Republik Indonesia/Papua New Guinea (RI/PNG) dalam mengolah dan memanfaatkan pangan lokal sebagai sumber asupan gizi. Metode pengabdian ini terdiri dari pelatihan dan pendampingan. Peningkatan capaian diukur menggunakan standar batas kelayakan program dan batas capaian perubahan. Program Kemitraan Masyarakat (PKM) telah berhasil meningkatkan pengetahuan dan kepedulian orang tua dari keluarga prasejahtera terhadap kebutuhan asupan gizi putra putrinya, dan meningkatkan keterampilan warga dalam menanam komoditas pangan lokal dengan memanfaatkan pekarangan rumah. Peningkatan keterampilan dapat dilihat dari hasil kreativitas warga dalam membuat kreasi makanan sesuai dengan konsep kecukupan gizi menggunakan pangan lokal.
\end{abstract}

Kata kunci: gizi, pangan lokal, warga prasejahtera, wilayah perbatasan

\begin{abstract}
The phenomenon of children suffering from malnutrition in the Asmat Regency, Papua Province is still the subject of national media coverage and is one of the benchmarks of the government's success in implementing pro-people programs. This community partnership activity is intended to increase knowledge, understanding, and skills of the parents of pre prosperous families live in the border regions of the Republic of Indonesia/Papua New Guinea (RI/PNG) in processing and utilizing local food as a source of nutritional intake. Method of the activity consisted of: training and mentoring. The improvement program uses standard limits on eligibility and limits on achievement of change. The Community Partnership Program (PKM) has succeeded in increasing the knowledge and care of parents of pre-prosperous families for the nutritional needs of their sons and daughters, and improving the parents' skills in growing local food using home yards. Increased skills can be seen from the results of the creativity of citizens in making food creations that are in accordance with the concept of adequate nutrition using local food
\end{abstract}

Keywords: local food, nutrition, pre-prosperous family, border area

\section{PENDAHULUAN}

Kabupaten Merauke adalah daerah yang terletak di Indonesia Timur, tepatnya di Provinsi Papua. Berdasar sumber Indonesia educational statistik in brief ((BPS) 2015) Papua terdiri dari 28 kabupaten, 1 kota, 470 distrik/kecamatan dan 4.375 kampung/desa. Luas wilayah Papua adalah 319.036.05 $\mathrm{km}^{2}$, dengan jumlah penduduk 3.064 .600 jiwa, serta dengan kepadatan $10 \mathrm{~km}^{2}$. 
Mayarakat yang tinggal di Kabupaten Merauke terdiri dari masyarakat lokal Papua dan pendatang. Jumlah penduduk yang semakin banyak menyebabkan mulainya ketimpangan dari bidang ekonomi dan kebutuhan pokok masyarakat di Papua. Walaupun adanya ketimpangan pangan akan tetapi masyarakat Papua tidak resah karena berdasar bunyi Undang-Undang No. 18 tahun 2012 memperbaharui definisi ketahanan pangan sebagai kondisi terpenuhinya pangan bagi negara sampai perseorangan, yang tercermin dari tersedianya pangan yang cukup, baik jumlah maupun mutunya, aman, beragam, bergizi, merata, dan terjangkau serta tidak bertentangan dengan agama, keyakinan dan budaya masyarakat, untuk dapat hidup sehat, aktif, dan produktif secara berkelanjutan.

Keberadaan kampung Sota adalah daerah yang berbatasan langsung dengan Negara Papua New Guinea (PNG). Kampung Sota adalah salah satu kampung yang berada pada wilayah Distrik Sota, Kabupaten Merauke, Provinsi Papua dengan jumlah penduduk sebanyak 1.940 jiwa yang terdiri dari laki-laki sebanyak 1.045 jiwa dan perempuan sebanyak 895 jiwa dengan jumlah KK sebanyak 489 dan wajib KTP sebanyak 1.349 jiwa. Secara geografis kampung Sota terletak pada posisi $1411^{\prime}-10000^{\prime} \mathrm{BT}$ dan $08025^{\prime}-45^{\prime} \mathrm{LS}$, batas wilayah sebelah utara berbatasan dengan Distrik Elikobel, sebelah selatan berbatasan dengan Distrik Merauke dan Neukenjerai, sebelah Timur berbatasan dengan Negara PNG dan sebelah barat berbatasan dengan Distrik Tanah Miring.

Negara yang kuat dan mampu bersaing dengan negara lain jika pemenuhan kebutuhan pokok sudah lebih dahulu tercukupi. Indikator pemenuhan kebutuhan pangan dapat dilihat dari kondisi kecukupan asupan gizi pada balita dan orang tua bayi. Indonesia merupakan negara yang memiliki sumber daya alam yang melimpah. Kekayaan harus diimbangi dengan kekayaan intelektual khususnya masyarakat harus menciptakan sesuatu yang bermanfaat dan berdaya guna tinggi (Nurlaila \& Yulastri 2017). Provinsi Papua merupakan salah satu provinsi yang masih mempunyai permasalahan gizi, hal ini dibuktikan dengan data yang disampaikan oleh Riset Kesehatan Dasar pada tahun 2013 tentang gizi dan pemenuhanya terdapat data bahwa prevalensi gizi kurang pada balita $(\mathrm{BB} / \mathrm{U}<2 \mathrm{SD})$ memberikan gambaran yang fluktuatif dari 18,4\% pada tahun 2007 menurun menjadi $17,9 \%$ pada tahun 2010 kemudian meningkat lagi menjadi 19,6\% pada tahun 2013.
Dua provinsi yang prevalensinya sangat tinggi ( $>30 \%$ ) adalah NTT diikuti Papua dan Papua Barat. Pelayanan kebutuhan penanggulangan permasalahan lanjut usia masih berkisar pada aspek kesehatan, ekonomi, dan sosial. Kebutuhan dasar secara batin (immaterial needs, basic needs atau psychological needs) masih kurang tersentuh (Moerdisuroso et al. 2018).

Data Indikator Kesejahteraan Rakyat tahun 2015 menyatakan rata-rata konsumsi kalori penduduk pada tahun 2014 sebanyak 1.859,30 kkal atau naik sebesar 16,55 kkal dibanding tahun sebelumnya yang tercatat sebesar 1.842,75 kkal, hal ini berarti konsumsi kalori per hari penduduk belum memenuhi syarat kecukupan gizi berdasarkan Widya Karya Pangan dan Gizi untuk tahun 2014 masih kurang sebanyak 290,70 kkal. Seperti halnya konsumsi kalori, rata-rata konsumsi protein per kapita juga mengalami peningkatan meskipun relatif kecil, yaitu dari 53,08 g pada tahun 2013 menjadi 53,91 g pada tahun 2014 protein yang dikonsumsi penduduk, yang berarti masih di bawah ketentuan atau batas kecukupan gizi yang direkomendasikan oleh Widya Karya Nasional Pangan dan Gizi. Perlu ditekankan bahwa anak selalu membutuhkan bantuan untuk menyesuaikan diri dan berkembang pada area kesehatan secara utuh (Marjo et al. 2017). Menurut data Provinsi Papua (2015) pada tahun 2013, hanya sebanyak 29,34\% penduduk Provinsi Papua yang memiliki tingkat konsumsi lebih besar atau sama dengan $90 \%$ AKG ( $\geq 1.800 \mathrm{kkal} /$ perkapita/hari), sebesar $29,63 \%$ untuk kategori 70-90\% (1.400-1.800 kkal/ perkapita/hari) dan masih ada sebanyak $41,04 \%$ atau 1,37 juta penduduk yang hanya mampu memenuhi kurang dari $70 \%$ KG $\quad(<1.400$ kkal/kapita/hari).

Lebih spesifik pada Kabupaten Merauke sebanyak $24,7 \%$ anak usia $12-23$ bulan di Kabupaten Merauke pada tahun 2014 yang telah menerima imunisasi lengkap sedangkan sisanya sebanyak 75,3\% belum menerima imunisasi lengkap. Berdasarkan harapan yang diamanahkan oleh Undang-Undang Negara Republik Indonesia, maka seharusnya Pulau Papua yang katanya "surga jatuh ke bumi" dapat makmur, berswasembada, dan mampu bersaing dengan wilayah Indonesia lainnya. Berdasar potensi yang dimilki oleh Papua, ternyata tidak hanya pertambangan saja yang menjadi idola akan tetapi juga pertanian merupakan komoditas yang patut mendapat apresiasi hal ini terbukti dengan ditetapkannya Kabupaten Merauke sebagai 
lumbung pangan Nasional dalam masterplan percepatan dan perluasan pembangunan ekonomi Indonesia (MP3EI) (Programme 2015).

Berdasar dari potensi Merauke harusnya bagian dari negara kesatuan Republik Indonesia ini dapat membuktikan diri mampu berswasembada. Fokus peningkatan kualitas pangan dapat dilakukan melalui upaya pemenuhan persyaratan kualitas pangan dengan menerapkan cara produksi pangan yang baik (Herlambang et al. 2018). Keberadaan masyarakat prasejahtera yang ada di perbatasan ditandai dengan batasan keluarga miskin atau keluarga prasejahtera (praKS) yang dicirikan dengan tidak bisa makan dua kali sehari, tidak memiliki pakaian yang cukup untuk berbagai kegiatan, kondisi atap, lantai dan dinding rumah tidak layak, tidak bisa mengakses sarana kesehatan karena katerbatasan biaya, dan anak usia sekolah yang tidak bisa bersekolah karena ketidakmampuan ekonomi (Burhanudin et al. 2018).

Masalah kecukupan dan gizi buruk merupakan alarm bagi semua stakeholder yang ada di Papua bahwa masalah pangan dan gizi adalah masalah bersama yang penanganannya juga harus dilakukan bersama. Kasus yang masih hangat di Papua adalah Keberadaan gizi buruk di Kabupaten Asmat, secara teritorial Kabupaten Asmat adalah hasil pemekaran kabupaten dari Merauke. Materi penyuluhan, pelatihan dan pendampingan dapat memberikan nilai manfaat, sesuai dengan pengalaman sesuai dengan masalah yang dihadapi, praktis sesuai dengan kebutuhan hal ini akan menimbulkan menarik dan partisipasi aktif dalam belajar (Yanti \& Permata 2016). Pemberdayaan masyarakat merupakan proses yang kompleks, tanpa henti (stop start proces) dan jangka panjang. Langkah yang dilakukan dalam pemberdayaan masyarakat melalui tahapan yang tidak bersifat sekuensial (Hogan 2000). Program pemberdayaan dalam meningkatkan ststus gizi harus dilakukan dengan pemberian pemahaman yang cukup, karena pengetahuan yang melekat dapat memberikan kebiasaan dan dalam jangka panjang dapat merubah kultur masyarakat kearah yang positif. Situasi keadaan di Provinsi Papua khususnya dapat dilihat dari pernyataan Gubernur Papua (2016) bahwa permasalahan pangan dan gizi secara lebih fokus dan berkesimbungan oleh seluruh pemangku kepentingan dalam payung Dewan Ketahanan Pangan Provinsi Papua, pengentasan, penuntasan masalah pangan dan gizi bersifat multidimensional yang tidak dapat dilakukan secara sendiri dan terpisah namun satu tatanan koordinasi yang tepat, cepat terarah, menyeluruh, dan berkesinambungan.

Melalui kegiatan Pengabdian pada Program Kemitraan Masyarakat ini, peran akademisi dapat mengimplementasikan teori langsung di lapangan guna mengastasi permasalahan serta memberikan solusi terhadap keadaan disekitar. Melalui kegiatan pengabdian ini dilakukan langkah nyata dan kongkret dimulai dari masyarakat lokal paham dalam mengetahui jenis pangan lokal termasuk kandungan zat gizinya, mengetahui cara memperoleh dan memeliharanya, serta dapat meningkatkan kualitas kreasi makanan lokal yang diolah tanpa harus mengurangi kandungan zat gizinya.

\section{METODE PELAKSANAAN KEGIATAN}

Kegiatan pengabdian masyarakat ini berlokasi di Kampung Sota, Distrik Sota, Kabupaten Merauke, Papua. Sasaran program kegiatan adalah warga prasejahtera serta balita yang ada di Kampung Sota, Distrik Sota. Mekanisme dari kegiatan pengabdian ini terbagi menjadi analisis kebutuhan dan pelaksanaan kegiatan yang terdiri dari pelatihan dan penerapan pendampingan, melalui kombinasi metode pengabdian diharapkan semua informasi dapat sampai efektif dalam meningkatkan pengetahuan dan wawasan peserta kegiatan pelatihan sehingga dapat dimanfaatkan untuk meningkatkan kualitas hidup (Nurjayadi \& Saraswati 2017). Sementara itu yang terakhir adalah evaluasi program pada warga masyarakat prasejahtera. Pengumpulan data dilakukan pada awal kegiatan dan akhir kegiatan guna mendapatkan perubahan yang terjadi setelah mengikuti kegiatan. Analisis data menggunakan data perbandingan antara sebelum dan sesudah kegiatan. Evaluasi kegiatan di analisis dengan dinilai dari batas kelayakan program pengabdian.

\section{Analisis Kebutuhan}

Analisis dilakukan pada awal program pegabdian berlangsung dengan mengedepankan kebutuhan warga dan permasalahan yang muncul pada kelompok masyarakat prasejahtera. Analisis dilakukan dengan cara wawancara tidak terstruktur serta observasi mendalam tentang keberadaan pangan lokal yang dapat menjadi solusi dalam program pengabdian ini. 


\section{Pelaksanaan}

Pelaksanaan dari program ini terdiri dari tiga kegiatan pada masing-masing kegiatan dapat dijelaskan sebagai berikut:

- Pelatihan, inti pokok dari kegiatan Program Kemitraan Masyarakat (PKM) meliputi tiga hal yang ada pada pelaksanaan program. Pelatihan yang dimaksud dalam kegiatan ini adalah pengumpulan warga prasejahtera baik secara kelompok maupun pelatihan yang dilakukan secara door to door guna memberikan pemahaman langsung tentang pentingnya asupan gizi dan bagaimana mencukupi gizi. Materi pelatihan meliputi pengenalan jenis pangan lokal yang ada di sekitar warga, kandungan zat gisi dari pangan lokal, cara budi daya pangan lokal dan kreasi olahan pangan lokal menjadi makanan yang beraneka ragam. Frekuensi pelatihan dilakukan secara bertahap yang dilakukan setiap minggu. Indikator perubahan pemahaman warga melalui pelatihan adalah berubahnya pola fikir warga yang dahulunya hanya mengenal pangan lokal saja dapat meningkat menjadi memahami kandungan zat gizi, cara mengolah dan juga pembudidayaan dari jenis pangan lokal.

- Penerapan, tahap selanjutnya dalam pelaksanaan program PKM ini adalah penerapan. Kegiatan yang dilaksanakan langsung kepada warga masyarakat sebagai mitra kegiatan melalui pelaksanaan praktik langsung dalam mengolah sumber pangan lokal sebagi olahan pangan yang kaya zat gizi. Secara khusus jenis olahan pangan lokal meliputi umbi-umbian, sayur-sayuran, dan lauk pauk dari hasil tangkapan hutan berupa daging rusa serta ikan.

- Pendampingan, setelah program penerapan yang sudah dilakukan maka selanjutya adalah pendampingan. Kegiatan pendampingan yang dilakukan berupa pemantauan warga dalam membuat dan menggunakan pangan lokal sebagai bahan olahan yang kaya gizi. Secara perlahan warga diberikan pendampingan mandiri sebagai konsekuensi dari pelatihan dan penerapan program PKM. Proses pendampingan dilakukan dengan membentuk kelompok kecil pada masing-masing warga. Melalui kelompok inilah dapat dilakukan pemantauan pelaksanaan dari implementasi materi pelatihan dan penerapan yang dilakukan sebelumnya. Usaha pendampingan dilakukan secara progresif dimulai dari penyerapan aspirasi tentang materi, proses penerapan dan juga menyerap masukan di luar dari jenis panga lokal yang sebelumnya belum diketahui endemik di tempat kegiatan program. Frekuensi pendampingan dilakukan setiap tiga minggu sekali dengan cara menemui kelompok kecil yang sudah dibagi sebelumnya.

\section{Evaluasi}

Langkah pelaksanaan dari PKM ini adalah evaluasi program. Evalusi menyangkut dari pelaksanaan program hingga evaluasi tanggapan dari warga sebagai mitra pengabdian. Materi dari evaluasi meliputi dua kegiatan, yaitu perubahan peningkatan warga dalam menyerap materi pengabdian tentang pangan lokal untuk gizi dan evaluasi pelaksanaan kegiatan pengabdian. Evaluasi pemahaman warga dilakukan dengan peningkatan jumlah setiap individu warga dan kelompok serta pemahaman tentang kandungan zat gizi yang meningkat dalam setiap periode evaluasi setiap satu bulan. Observasi dilakukan dengan pertimbangan hasil refleksi dari Mitra satu, yaitu petugas kesehatan yang ditugaskan dari puskesmas Distrik Sota. Pengumpulan data dalam PKM ini menggunakan instrumen angket dan wawancara langsung kepada mitra. Selain kepada warga untuk mengukur keterlaksanaan program juga dilakukan pengukuran oleh mitra 2, yaitu petugas Puskesmas Sota. Analisis data yang digunakan pada hasil pengumpulan data menggunakan persentase.

\section{HASIL DAN PEMBAHASAN}

\section{Analisis Kebutuhan Mitra}

Data yang sudah didapatkan sesuai dari petugas Kelurahan Sota terdapat jumlah warga, dari jumlah tersebut terdapat 29 KK yang merupakan kelompok keluarga prasejahtera. Kehidupan warga prasejahtera yang berada di daerah perbatasan RI/PNG merupakan warga asli Papua yang sudah lama tinggal di daerah tersebut. Keadaan ekonomi yang hanya mengandalkan hasil hutan menyebabkan ekonomi warga masih rendah. Selain keadaan ekonomi warga, observasi tingkat kesehatan warga prasejahtera yang masih belum mandiri. Pantauan keberadaan tingkat kesehatan yang ditemui pada warga didapatkan data dari Puskesmas Sota utamanya pada balita, masih banyak ditemui keberadaan gizi yang rendah. Hal ini menurut penuturan dari petugas Puskesmas dikarenakan keberadaan perkampungan warga yang masih bergantung 
dari alam. Hasil analisis kebutuhan juga menganalisis jumlah dan jenis pangan lokal yang ada di sekitar tempat tinggal mitra. Jenis pangan lokal yang ditemui meliputi hasil alam sayursayuran, hasil tanaman pekarangan umbiumbian serta hasil tangkapan dari hutan yang berupa daging rusa dan hasil tangkapan ikan. Melimpahnya pangan lokal yang ada dapat diketahui dengan rasa enggan warga untuk mengolah karena terlalu banyak.

\section{Pelaksanaan}

Program kemitraan ini didasarkan pada hasil analisis kebutuhan sebelumnya. Pada pelaksanaan PKM ini dilakukan pada warga prasejahtera yang sudah dilakukan analisis kebutuhan sesuai dengan tujuan program. Kegiatan PKM ini dilaksanakan selama hampir lima bulan akan tetapi tidak penuh di lakukan di tempat, hal ini karena pada awal pelaksanaan sudah dilakukan program secara intens dan selanjutnya tinggal dilakukan pendampingan secara terstruktur. Kegiatan PKM yang dilaksanakan terdiri dari pelatihan, penerapan, pendampingan, dan evaluasi.

\section{- Pelatihan}

Pelatihan yang sudah dilakukan warga masyarakat Kampung Sota diselenggarakan di balai Kampung Sota. Atas izin dari kepala Kampung Sota bapak Adolof Mbanggu dan kerja sama dengan Puskesmas Sota, dilakukan pelatihan dalam menyiapkan olahan bahan makanan. Pada tahap pelatihan dilakukan pemberian contoh dari jenis makanan yang mengandung gizi tertentu, dan selanjutnya Tim melakukan demonstrasi yang di ikuti oleh warga masyarakat. Pada pelatihan ini selain terjadi interaksi saling membantu antara Tim dan warga juga terjadi tanya jawab seputar penggunaan olahan pangan yang sederhana dan praktis. Setelah demonstari dari tim selanjutnya warga dipersilahkan membuat secara bersama-sama olahan dari pangan lokal. Adapun hasil dari kreasi makanan yang telah di hasilkan selanjutnya dibagikan kepada warga dan dipersilahkan menilai sendiri-sendiri. Jenis pengolahan yang diajarkan sebenarnya tidak jauh berbeda dari cara olah masyarakat sebelumnya. Serta peralatan yang digunakan juga tidak memerlukan peralatan yang canggih dan memerlukan biaya yang mahal. Secara sederhana dijelaskan cara mengolah meliputi, merebus, mengukus, dibakar dan juga menggoreng. Olahan sayur mayur dipadukan dengan bubur dan ikan yang bisa langsung dinikmati oleh balita. Olehan sagu yang dibuat dalam bentuk kue aneka rasa yang dapat menambah selera tanpa harus mengganti dengan bahan beras dan jagung.

\section{- Penerapan}

Setelah warga diberikan pelatihan yang intensif, melalui pengetahuan dan pemahaman maka hal yang selanjutnya dilakukan pada program ini adalah melaksanakan penerapan. Hal yang perlu digaris bawahi dalam tahap penerapan adalah praktik langsung dan tim hanya bekerja sebagai media saja. Warga masyarakat diberikan keleluasaan dalam mengekpresikan bahan dan olahan pangan lokal yang dimiliki selanjutnya membuat praktik. Hasil makanan yang telah disajikan selanjutnya diberikan komentar dari cara pemasakan, bahan dan hasil dari kandungan gizinya. Melalui bekerja secara mandiri mitra dituntut untuk berkreasi menurut kemampuan dan imaginasinya. Kesulitan dalam tahap penerapan ini adalah banyaknya warga yang merasa tidak percaya diri dalam memasak dan mengolah makanan. Hal ini disadari bahwa kebiasaan dari warga adalah hanya mengonsumsi secara langsung tanpa melakukan kreasi olahan pangan. Melalui penerapan ini juga dijelaskan langsung kepada warga dan Mitra bahwa olahan dan cara mengolah bahan pangan lokal dimaksudkan untuk memberikan solusi pasti tentang pencukupan kebutuhan gizi khususnya balita, serta memberikan kreasi baru cara mengolah, cara menyajikan, dan cara mengkreasikan jenis olahan pangan lokal yang dapat di gunakaan sebagai sarana pemenuhan kebutuhan gizi balita. Manfaat dari kegiatan ini dapat difahami oleh masyarakat baik secara praktik maupun teori. Adapun hasil dari kegiatan penerapan terlihat pada Gambar 1.

\section{- Pendampingan}

Keberadaan tim pada lingkungan masyarakat yang tinggal di daerah perbatasan RI/PNG

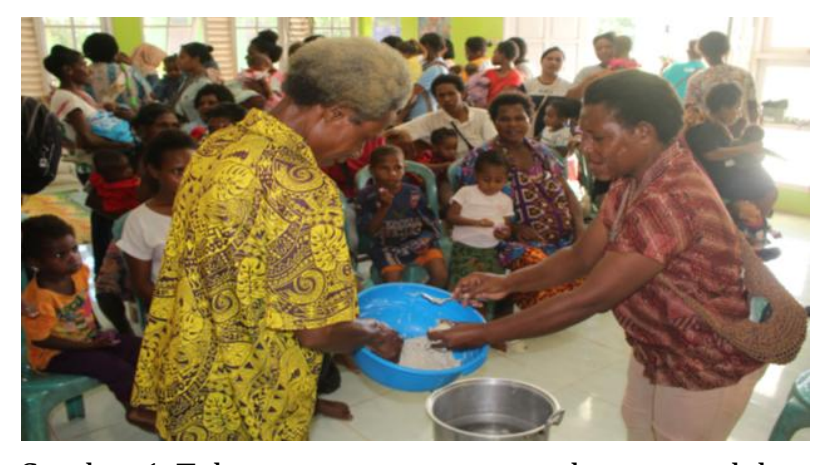

Gambar 1 Tahap penerapan pembuatan olahan pangan lokal. 
tepatnya di daerah Sota, dimaksimalkan dengan melakukan pendampingan langsung kepada warga. Hal yang dilakukan dalam tahap pendampingan adalah terjun langsung ke rumahrumah warga dan melakukan pendampingan secara komunikasi dan juga secara ilmu. Melalui pendampingan ini didapatkan bahan refleksi terhadap hasil pelaksanaan program. Warga secara antusias mendukung dan memberikan masukan tentang kelebihan dan kekurangan program yang dialami langsung oleh masyarakat. Pada kegiatan pendampingan hal yang pokok dan sangat penting adalah pemberian asupan anakanak balita yang berasal dari warga prasejahtera. Melalui kegiatan ini harapan warga dapat diberikan ilmu yang relatif permanen dalam mencukupi kebutuhan gizi putra-putrinya. Pendampingan juga dilakukan dengan membuat pos dalam kelompok kecil yang mana melalui kelompok kecil tersebut dapat memberitahu kesulitan dan solusi dalam menerapkan materi. Pendampingan juga melibatkan mitra Puskesmas Sota yang dapat di hubungi dan menjadi pusat informasi baik untuk bertanya dan berdiskusi warga.

\section{- Evaluasi}

Evaluasi dilakukan setelah keseluruhan kegiatan dilaksanakan yang meliputi pelatihan, penerapan, dan pendampingan. Monitoring evaluasi dilakukan melalui pengisian kuis dan wawancara langsung kepada warga masyarakat. Adapun secara jelas hasil evaluasi program terlihat pada Gambar 2.

Berdasarkan hasil analisis data diketahui bahwa evaluasi dari pelaksanaan pengabdian kemitraan masyarakat yang sudah dilakukan diketahui bahwa tingkat rerata yang disampaikan mitra sudah di atas batas layak. Batas layak yang digunakan dalam analisis evaluasi pelaksanaan program meliputi indikator keberhasilan minimal yang terdiri indikator tanggapan warga secara rerata, kebermanfaatan program sebelum dan sesudah program, kebutuhan warga, serta indikator tingkat partisipasi warga. Berdasarkan pelaksanaan tanggapan warga diketahui mitra dari warga prasejahtera pada tingkat 3,52. Pada azas kebermanfaatan program diakui oleh mitra satu, yaitu puskesmas dan mitra dua warga prasejahtera yang sangat mendukung adanya program ini. Berbeda dengan sebelumnya tingkat pelaksanaan program berdasarkan kebutuhan asupan gizi sangat dirasakan bagi warga prasejahtera dan warga masyarakat, serta pada tingkat pemahaman pada program yang sudah dilaksanakan terdapat rerata di atas batasan layak, yang dirasakan oleh mitra satu, warga prasejahtera dan warga masyarakat pada umumnya. Berdasar penuturan warga diketahui bahwa selain tingkat pemahaman warga meningkat, penyampaian materi menggunakan strategi pelatihan, penerapan, dan pendampingan membawa kebermanfaatan yang sangat luas. Melalui program ini setelah penerapan biasanya yang dialami oleh warga adalah pemateri langsung meninggalkannya begitu saja, sehingga warga hanya sekedar tahu dan melakukan pada saat itu saja, akan tetapi pada program ini masih ada satu langkah penyampaian program, yaitu pendampingan. Melalui perbedaan inilah dampak yang dirasakan oleh warga sangat dirasakan oleh warga.

Program PKM ini berjalan lancar, akan tetapi dalam kenyataan dilapangan juga ditemukan kendala pelaksanaan. Adapun kendala yang dihadapi dari program ini adalah pertama, cara penyampaian informasi kepada warga masyarakat. Hal ini dikarenakan warga masyarakat

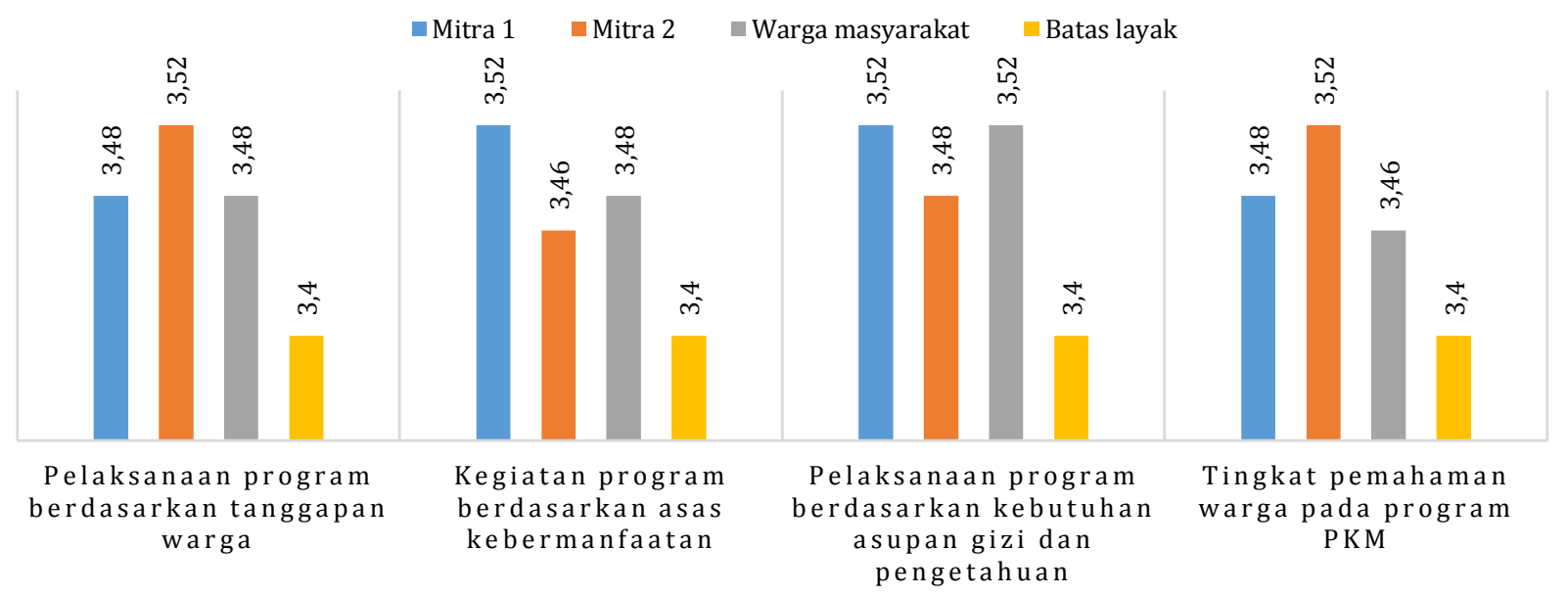

Gambar 2 Evaluasi pelaksanaan pengabdian kemitraan masyarakat. 
masih banyak yang tinggal di tengah hutan untuk mencari kebutuhan hidup. Setelah informasi disampaikan kendala pengumpulan warga yang masih sulit, karena banyak warga yang sudah terbiasa jika mendapat informasi untuk berkumpul maka akan mendapatkan bantuan dari pemerintah. Kedua, permasalahan pemahaman warga yang masih enggan dan malas tau dengan menjaga kesehatan baik diri sendiri maupun kesehatan anak-anaknya, hal ini terjadi karena tugas menjaga kesehatan dan memelihara seorang anak adalah tugas seorang ibu, sedangkan orang tua laki-laki mempunyai tugas mencari nafkah untuk keluarganya. Ketiga, masalah gizi bagi warga masih dianggap sebagai kebutuhan nomor sekian, karena sudah tumbuh pemikiran bahwa hal makanan yang dibutuhkan adalah kenyang itu saja sudah sangat cukup. Pengolahan makanan yang sudah biasa dilakukan oleh warga adalah dengan dibakar dan direbus, hal ini dikarenakan kepraktisan dan biaya yang harus dikeluarkan.

Dampak dari program ini bisa dikatakan sangat mengena di masyarakat. Hal ini dikarenakan ternyata pada zaman modern ini warga yang mendiami di daerah perbatasan sangat terbuka dengan pengetahuan baru, salah satunya tentang pengetahuan gizi indikatornya adalah warga yang sudah mau menerima keilmuan baru dalam mencukupi gizi dan cara mendapatkannya. Dampak lainnya walaupun belum bisa mengubah kultur masyarakat tentang kesadaran pemilihan dan pengolahan makanan lokal menjadi sumber gizi yang baik, akan tetapi warga sudah mulai sadar dengan menanam pangan lokal di sekitar rumah dengan jenis dan ragam yang berbeda indikator peningkatan adalah warga telah sadar menanam dan bercocok tanam dan mengolah lahan disekitar pekarangan rumah. Dampak lain adalah secara bertahap tingkatan asupan gizi balita warga prasejahtera di daerah perbatasan sudah meningkat. Indikator dari peningkatan pencukupan asupan gizi adalah orang tua dari warga prasejahtera dapat memberikan asupan makanan yang beragam pada anak-anaknya. Olahan pangan lokal yang berkualitas akan memberikan dampak pada perbaikan gizi demi pertumbuhan dan perkembangan anak. Meningkatnya pertumbuhan anak dapat diperoleh dari Puskesmas Sota yang meneyelanggarakan Posyandu setiap tanggal 10 pada tiap bulan, diperoleh bahwa terjadi peningkatan rata-rata tinggi dan bobot badan anak yang semakin meningkat walaupun tidak pada keseluruhan balita. Asupan gizi yang bertahap dan pemenuhan gizi melalui makanan sehat dan bervariasi dapat meningkatkan berat status gizi anak balita (Sumarsono \& Anisah 2018).

Upaya keberlanjutan dari program ini, dilakukan bukan sebatas pemberi informasi saja. Jika seperti yang dituturkan warga sebelumnya bahwa banyaknya program penyuluhan hanya efektif pada saat dan waktu berjalan saja. Pada program ini keberlanjutan program dapat terukur dan terstruktur melalui pendampingan program secara berkelanjutan. Karena jarak mitra dan kampus yang jauh maka sebagai upaya keberlanjutan program dilakukan melalui pengawalan oleh mitra kedua, yaitu puskesmas yang membuka posko khusus dalam konsultasi pemenuhan gizi masyarakat sekitar perbatasan RI/PNG.

\section{SIMPULAN}

Kegiatan program PKM yang sudah dilaksanakan sesuai dengan alur dan tahapan yang sudah direncanakan. Pelaksanaan program mendapatkan tercapainya tujuan pengabdian, serta hasil yang diharapkan dapat tercapai sesuai dengan tujuan awal pengabdian. Pemanfaatan pangan lokal sebagai sumber asupan gizi bagi balita prasejahtera dapat terlaksana. Hal ini dibuktikan dengan efek jangka pendek sudah timbulnya rasa peduli akan kesehatan, asupan makanan, serta kandungan gizi yang diperlukan oleh balita prasejahtera. Menurut warga Kampung Sota yang menjadi ojyek pada kegiatan pengabdian ini dapat disimpulkan bahwa jenis pengolahan dan cara pengolahan yang diajarkan langsung kepada warga dapat diterima. Kebiasaan warga dalam mengolah Ikan yang tadainya hanya di bakar kini berubah dengan melakukan pengolahan yang bervariasi dengan memadukan olahan pangan lokal lainnya. Warga kampung Sota yang merpakan warga yang mendiami daerah perbatasan RI/PNG mengaku mendapat kesempatan dalam meningkatkan asupan gizi melalui program pelatihan, penerapan dan pendampingan yang di laksanakan melalui program PKM. Saran yang disampaikan melalui hasil PKM ini adalah adanya partisipasi aktif masyarakat dalam melihat, mendengar dan melakukan tindakan khususnya bagi saudarasaudara yang berada di daerah perbatasn RI/PNG. 


\section{UCAPAN TERIMA KASIH}

Kegiatan PKM ini di danai oleh Direktorat Jenderal Riset dan Pengembangan dari Kementerian Riset, Teknologi dan Pendidikan Tinggi. Kegiatan pengabdian ini di danai oleh SIMLIBTABMAS DIKTI tahun 2019 pada skim Program Kemitraan Masyarakat dengan Nomor Kontrak 064.2/UN52.8/PM/2019. Oleh karena itu, ucapan terima kasih kepada LPPM Universitas Musamus, Mitra Puskesmas Sota dan warga Kampung Sota, Distrik Sota, serta semua pihak yang telah membantu terlaksananya program PKM ini.

\section{DAFTAR PUSTAKA}

[BPS] Badan Pusat Statistik. (2015). Katalok BPS Indikator Kesejahteraan Rakyat. Jakarta (ID): BPS Press.

Burhanudin, Sarianti T, Mintarti. 2018. Penumbuhan Kelompok "Cassava Chips" Berbasis Keluarga Prasejahtera di Kelurahan Menteng dan Desa Neglasari. Agrokreatif Jurnal Ilmiah Pengabdian kepada Masyarakat. 4(2): 165-173. https://doi.org/10.29244/ agrokreatif.4.2.165-173

Herlambang A, Asmawati E, Haryono Y. 2018. Implementasi Cara Produksi Pangan yang Baik untuk Industri Rumah Tangga Kerupuk di Sidoarjo. Agrokreatif Jurnal Ilmiah Pengabdian kepada Masyarakat. 4(1): 31-37. https:// doi.org/10.29244/agrokreatif.4.1.31-37

Hogan C. 2000. Facilitating Empowerment: a handbook for facilitators, trainers, and individuals. Amerika (US): Stylus Publishing Inc.

Marjo HK, Cahyawulan W, Fitriyani H. 2017. Bimbingan Kelompok Untuk Meningkatkan Pemahaman Kekerasan Seksual Untuk Peserta
Didik Sekolah Menengah Pertama Di Kecamatan Bantar Gebang. Sarwahita: Jurnal Pengabdian Kepada Masyarakat. 14(2): 9498. https://doi.org/10.21009/sarwahita. 142.02

Moerdisuroso I, Oetopo A, Yufiarti. 2018. Pemberdayaan Lansia Melalui Kreasi Seni. Sarwahita: Jurnal Pengabdian Kepada Masyarakat. 15(2): 89-96. https://doi.org/ 10.21009/sarwahita.152.03

Nurjayadi M, Saraswati LA. 2017. Pemanfaatan Obat-Obat Tradisional Dalam Mencegah Dan Mengobati Penyakit Typhus Sebagai Upaya Peningkatan Hidup Sehat Pada Masyarakatpagesangan Barat Mataram. Sarwahita: Jurnal Pengabdian Kepada Masyarakat. 14(2): 114-122. https://doi.org/ 10.21009/sarwahita.142.05

Nurlaila, Yulastri L. 2017. Pemberdayaan Ibu-Ibu PKK Kelurahan Rawamangun Dalam Pelatihan Pembuatan Decoupage Dari Tissue Berbasis Industri Kreatif. Sarwahita: Jurnal Pengabdian Kepada Masyarakat. 14(2): 151-155. https:// doi.org/10.21009/sarwahita.142.10

Programme WF. 2015. Peta Ketahanan dan Kerentanan pangan Papua. Jayapura (ID): Dewan Katahanan Pangan Papua.

Sumarsono A, Anisah A. 2019. Media Audio Visual sebagai Solusi Efektif Pembelajaran Teknik Gerak. Jurnal Pendidikan Jasmani dan Olahraga, 4(1): 103-110. https://doi.org/ 10.17509/jpjo.v4i1.12298

Yanti D, Permata DA. 2016. Pemberdayaan Masyarakat Tani melalui Pengembangan Produk Olahan Ikan di Nagari Tarung-tarung, Kecamatan Rao, Kabupaten Pasaman Sumatera Barat. Agrokreatif Jurnal Ilmiah Pengabdian kepada Masyarakat. 2(2):73-80. https://doi.org/10.29244/agrokreatif.2.2.7380 